BRAIN. Broad Research in Artificial Intelligence and Neuroscience

ISSN: 2068-0473 | e-ISSN: 2067-3957

Covered in: Web of Science (WOS); PubMed.gov; IndexCopemicus; The Linguist List; Google Academic; Ulrichs; getCITED; Genamics JoumalSeek; J-Gate; SHERPA/RoMEO; Dayang Journal System; Public Knowledge Project; BIUM; NewJour; ArticleReach Direct; Link+; CSB; CiteSeerX; Socolar; KVK; WorldCat; CrossRef; Ideas RePeC; Econpapers; Socionet.

2021, Volume 12, Issue 3, pages: 303-318 | https://doi.org/10.18662/brain/12.3/233

\section{A Content Analysis on Publications Written on (E-Government and M-Government) from 2000 to 2021}

\author{
Huseyin BİCEN ${ }^{1}$, \\ Shobo Najim SHALİ² \\ ${ }^{1}$ Near East University, Cyprus, \\ huseyin.bicen@neu.edu.tr \\ ${ }^{2}$ KPI Research Center, Iraq, \\ shoboshali@hotmail.com
}

Abstract: The ICT (Internet Communication Technology), with the assistance of Web 2.0 tools, made a revolutionary impact on organizational performances, including the governmental ones. The Electronic Government or (E-Government) is a modern approach that contributes positively to the governmental organization's performances; it leads to a structural reforms and creates an innovative atmosphere in the flow of information. The Mobile Government or (M-Government) created by the technology innovators to add better efficiency to the governmental organizations works for saving time and efforts. Between 2000 and 2021, this study looked at publications that supported E-Government and M-Government that were published on the Scopus website or contributed to the Scopus database.

Keywords: E-Government, M-Government, e-government, mgovernment. E-gov, m-gov, government data processing.

How to cite: Bicen, H., \& Shali, S.N. (2021). A Content Analysis on Publications Written on (E-Government and M-Government) from 2000 to 2021. BRAIN. Broad Research in Artificial Intelligence and Neuroscience, 12(3), 303318. https://doi.org/10.18662/brain/12.3/233 


\section{Introduction}

In recent years, the demands on Smartphones increased incredibly (Silver, 2019). It became a necessary gadget for most of people. Young and old, even children demanding to own one of those smartphones for incredible capabilities in connecting to others and using advanced applications, like if you were completing your work with your palm of your hand. On the other hand, Advanced governments in the race for innovations and creating better tools for their types of work in serving their people (OECD 2017), by offering advanced solutions to their employees to provide better efficiency in technology base tools. From this angle, the egovernment and the mobile government applications are created in supports of good governance. Around the world, advancements in E-governmentoriented technologies and services are happening at a breakneck pace. Egovernment initiatives attempt to profit from the most cutting-edge types of information technology, notably web-based Internet applications, in order to improve government's core tasks. These functions are currently spreading the usage of mobile and wireless technology, paving the way for a new path: Government on the move (m-government) (Kushchu \& Kuscu, 2016).

The ICT (Internet Communication Technology) devices, with assistance Web 2.0 tools, allow multiple functions simultaneously (Bicen et al., 2012) and made a revolutionary impact on organizational performances, including governmental organizations. The e-government is a modern approach that contributes positively to the governmental organization's development; it leads to structural reforms and creates a creative atmosphere in the flow of information. Consequently, it will generate better performances from the government sides to serve their citizens better, leading to transparency and trust.

E-government solutions strive to improve government essential activities by utilizing the most cutting-edge kinds of information technology, particularly web-based Internet applications. These functions have now expanded mobile and wireless technologies, resulting in a new trend: mobile government (m-government) (Kushchu \& Kuscu, 2016).

Further to the e-government developments, the mobile government supported by Smartphones creates an extra efficient tool for serving people from the comforts of their palms. The" at any time ... anywhere...." approach saves both governments and citizens time and effort. It changes the faces of organizations. Technology innovation is not going to stop at this point. With upcoming internet advancements of the G6, new technology in the 
governmental institutions will arise under the Smart Government. This new approach is underway to make governments' organizations even more efficient and accessible to their citizens. This study aims to analyze the literature using e-government and its sub-setting tool "m-government technologies" in terms of various variables, give better guidance for future studies and research, and pinpoint the gap areas of studies regarding this specific subject.

\subsection{The goal of the study}

This study aims to understand the amount of interest shown from different sectors to the Mobile Government (M-Gov.) researches with in the Electronic Government (E-Gov.) approach, from academics, scholars, and other professionals levels. In addition what has being published on Scopus website.

\subsection{Hypothesis}

The following sub-objectives have been determined to help achieve the overall goal:

1. What is the distribution map of studies using the e-government and $\mathrm{m}$-government aspects according to the publication type?

2. What is the distribution map of studies that use the e-government and $\mathrm{m}$-government aspects by year of publication?

3. How is the distribution map of publications using the egovernment and m-government aspects according to the number of authors?

4. What are the disciplines where articles about e-government and $\mathrm{m}$-government publications used?

5. How is the distribution of studies using the e-government and $\mathrm{m}$ government publications according to the country of interest?

\section{Method}

The quantitative method is used to assess the content analysis for the electronic-government (e-government) and the mobile-government (mgovernment) publications. Content analysis is a research method that seeks to make repeatable and accurate conclusions about concepts from text and documents (Krippendorff, 2012). In another definition, content analysis is an unbiased and quantitative examination of the main substance of communication (Berelson, 1952). It can also be used to look for trends and patterns in documents (Stemler, 2000). 


\subsection{Scanning Criteria}

The researcher determined certain scanning and selecting criteria to determine the project procedure in this investigation (Jawabreh \& Bicen, 2020). After defining the requirements, the terms searched basis on the criteria keywords "e-gov." and "m-gov" as well as "Electronic Government" and "Mobile Government" in the database of (Scopus) database to find all publications posted between the years 2000-2021. The results, 184 publications were found by the researcher within the contexts of the field in multiple categories. These articles were found to meet the criteria established at the end of the screening process. "Publishing types, publication years, authors, the discipline areas, the publication's country of origin, and their volumes" were all examined.

\subsection{Sample}

All samples included from 2000 to 2021, the research sample includes papers about e-government and m-government discovered in the titling literature on the (Scopus) database. As a consequence of the research, many categories were investigated, and investigations were supported based on the data presented.

\subsection{Data Collection and Analysis}

The information gathered for the study was evaluated using descriptive statistical approaches, such as percentages and frequencies (Jawabreh \& Bicen, 2020). To meet the answer to each study question, the rates of the data were calculated based on the frequencies and given in tables.

\section{Findings and Comments}

\subsection{Distribution of Projects by Publication Type}

The distribution map of studies on the use of "e-government and $\mathrm{m}$ government" includes term equivalencies like "Electronic Government, Mobile Government, E-Gov., and M-Gov", analyzed by types of studies. The highest number of publication type appeared to be a Conference Papers with 48.92\%, followed by Articles 32.06\%, Book Chapters 14.13\%, Conference Reviews 3.27\%, and each of (Book, Editorial and Review Papers) with less than $1 \%$ which was $0.54 \%$. 
(Table 1) The Distribution of Projects on e-government AND m-government to their Publication Type)

Source: Authors own conception

\begin{tabular}{lll}
\hline Publication/ Document Types & Number of Articles & $\mathbf{\%}$ \\
\hline Conference Paper & 90 & $49.5 \%$ \\
\hline Article & 59 & $32 \%$ \\
\hline Book Chapter & 26 & $14 \%$ \\
\hline Conference Review & 6 & $3 \%$ \\
\hline Book & 1 & $0.5 \%$ \\
\hline Editorial & 1 & $0.5 \%$ \\
\hline Review & 1 & $0.5 \%$ \\
\hline Total & $\mathbf{1 8 4}$ & $\% 100$
\end{tabular}

\section{Types of Publications}

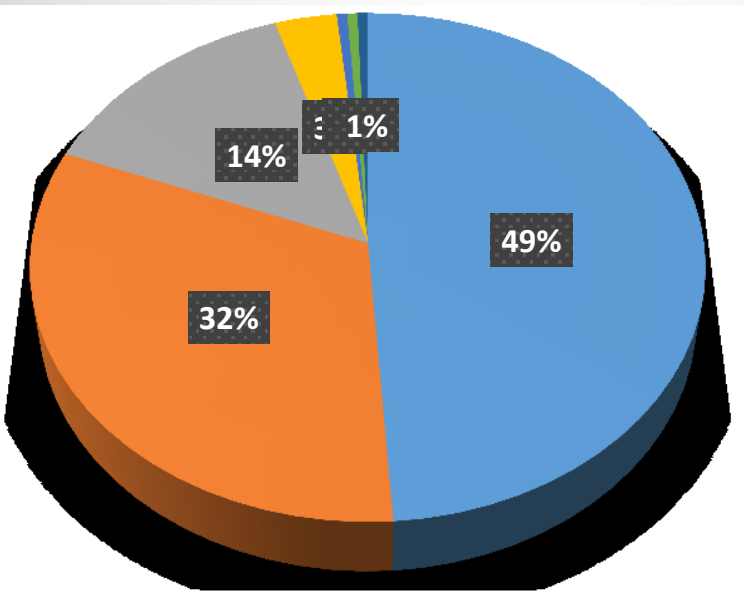

- Conference Paper

article

Book Chapter

Conference Review

- Book

- Editorial

neview

\subsection{Distribution of Projects by Publishing Years}

When the distribution map of studies on the use of "e-government and m-government" includes term equivalencies like "Electronic Government, Mobile Government, E-Gov., and M-Gov", the highest number of studies were analyzed by years observed between 2000-2021 with $8.7 \%$ in 2020. These studies came after those conducted in 2010 with $8.2 \%$ and in 2013 and 2014 with 7.6\%. However, 3.3\% of studies published in the 
recent year 2021 so far, and this rate might change by the end of this year as other scholars might add to this table of accomplishment.

(Table 2) The Distribution of Projects on e-government AND m-government to their Publishing Years

Source: Authors own conception

\begin{tabular}{|c|c|c|c|c|c|}
\hline $\begin{array}{c}\text { Publishing } \\
\text { Years of } \\
\text { Studies }\end{array}$ & $\begin{array}{l}\text { Number } \\
\text { of Articles }\end{array}$ & $\%$ & $\begin{array}{c}\text { Publishing } \\
\text { Years of } \\
\text { Studies }\end{array}$ & $\begin{array}{l}\text { Number of } \\
\text { Articles }\end{array}$ & $\%$ \\
\hline 2000 & 0 & $\% 0$ & 2011 & 13 & $\% 7$ \\
\hline 2001 & 0 & $\% 0$ & 2012 & 11 & $\% 6$ \\
\hline 2002 & 0 & $\% 0$ & 2013 & 14 & $\% 7.6$ \\
\hline 2003 & 1 & $\% 0.54$ & 2014 & 14 & $\% 7.6$ \\
\hline 2004 & 1 & $\% 0.54$ & 2015 & 12 & $\% 6.5$ \\
\hline 2005 & 1 & $\% 0.54$ & 2016 & 12 & $\% 6.5$ \\
\hline 2006 & 4 & $\% 2.17$ & 2017 & 12 & $\% 6.5$ \\
\hline 2007 & 7 & $\% 3.8$ & 2018 & 11 & $\% 6$ \\
\hline 2008 & 10 & $\% 5.4$ & 2019 & 14 & $\% 7.6$ \\
\hline 2009 & 10 & $\% 5.4$ & 2020 & 16 & $\% 8.7$ \\
\hline \multirow[t]{2}{*}{2010} & 15 & $\% 8.2$ & $\begin{array}{l}2021 \text { (in } \\
\text { progress) }\end{array}$ & 6 & $\% 3.3$ \\
\hline & & & Total & 184 & $\% 100$ \\
\hline
\end{tabular}




\section{Publications per Year}

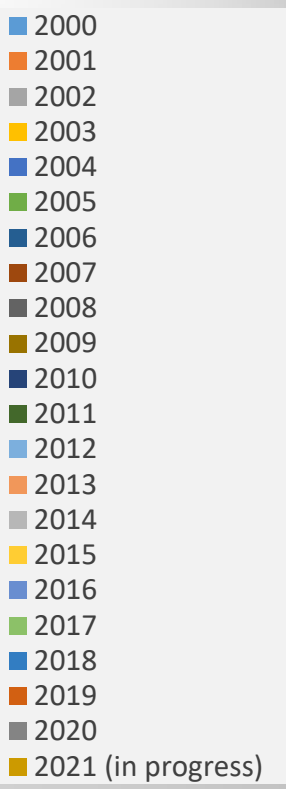

\subsection{How is the distribution of publications using "e-government and m-government" according to the number of authors?}

When it comes to the number of authors, there are numbers of them. in "e-government and m-government" studies, six levels of contributions and 239 authors contributed to 184 publications. That means multiple people contributed to the same publications. In other words, some articles were published under more than one author. On the other hand, some authors contributed to more than one publication. The single highest contributing author contributed to five publications. Three authors contributed to four journals, and 12 authors contributed to 3 publications, followed by 37 authors with two publications and 106 singled publication authors. However, in this research, six undefined fields of authors were founded.

(Table 3) The Distribution of Articles Using "e-government and m-government" According to the Number of Authors)

Source: Authors own conception

\begin{tabular}{cccc}
\hline $\begin{array}{c}\text { Highest } \\
\text { Contributors }\end{array}$ & Number of Authors & $\begin{array}{c}\text { Numbers of } \\
\text { Publication }\end{array}$ & $\begin{array}{c}\text { Contribution } \\
\text { Percentage }\end{array}$ \\
\hline 1 & 1 Author & 5 Publications & 3.125 \\
\hline 2 & 3 Authors & 4 Publications & 2.5
\end{tabular}




\begin{tabular}{cccc}
\hline 3 & 12 Authors & 3 Publications & 1.875 \\
\hline 4 & 37 Authors & 2 Publications & 1.25 \\
\hline 5 & 106 Authors & 1 Publications & 0.625 \\
\hline 6 & 6 Undefined Authors & Undefined & 0.625 \\
\hline Total & $\mathbf{1 8 4}$ & & $\mathbf{1 0 0 \%}$
\end{tabular}

Publications

\section{Authors Contribution Percentage}

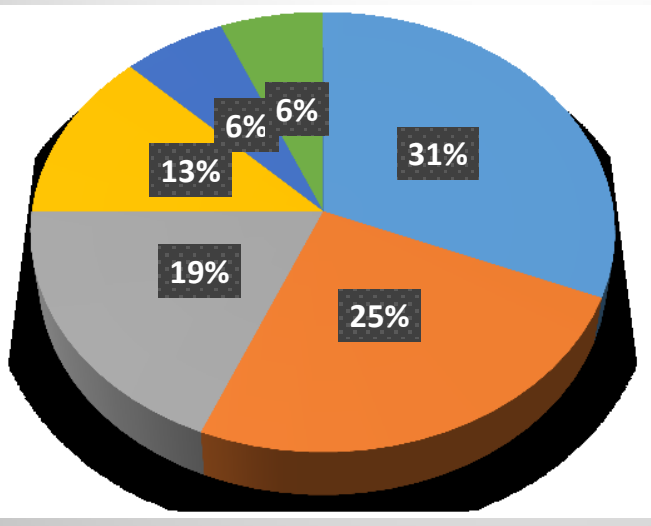

1 Author 5 Publications

— 3 Authors 4 Publications

n 12 Authors 3 Publications

37 Authors 2 Publications

ص 106 Authors 1 Publications

- 6 Undefined Authors

\subsection{What are the disciplines where articles about "e-government and m-government"?}

Regarding the discipline areas of "e-government and $\mathrm{m}$ government," the disciplines covered in related publications are listed in alphabetical order (Table 4). There are 325 disciplines in total in the study, which are divided into 15 groups. The field of Computer Science has the greatest studies in these disciplines with 42.76 percent, which is the highest one, and followed by Social Sciences of $18.76 \%$. Business, Management and Accounting at 10.46\%, Engineering 8.61\%, Decision Sciences 8.31\%, Mathematics 5.84\%, Economics, Econometrics, and Finance 1.24\%, both Multidisciplinary and Physics and Astronomy 0.93\%, Environmental Science $0.61 \%$, and each of (Agricultural and Biological Sciences, Arts and Humanities, Energy, Materials Science, plus Medicine) participated by less than $1 \%$, which was equivalent to $0.31 \%$ of the total discipline. 
A Content Analysis on Publications Written on (E-Government and ... Huseyin BICEN \& Shobo Najim SHALI

(Table 4) The distribution map of the discipline areas about "e-government and mgovernment" in the articles on Scopus

Source: Authors own conception

\begin{tabular}{clcc}
\hline \multicolumn{1}{c}{ Research Topics } & $\begin{array}{c}\text { Number } \\
\text { of Articles }\end{array}$ & $\%$ \\
\hline 1 & Computer Science & 139 & 42.76 \\
\hline 2 & Social Sciences & 61 & 18.76 \\
\hline 3 & Business, Management, and Accounting & 34 & 10.46 \\
\hline 4 & Engineering & 28 & 8.61 \\
\hline 5 & Decision Sciences & 27 & 8.31 \\
\hline 6 & Mathematics & 19 & 5.84 \\
\hline 7 & Economics, Econometrics and Finance & 4 & 1.24 \\
\hline 8 & Multidisciplinary & 3 & 0.93 \\
\hline 9 & Physics and Astronomy & 3 & 0.93 \\
\hline 10 & Environmental Science & 2 & 0.61 \\
\hline 11 & Agricultural and Biological Sciences & 1 & 0.31 \\
\hline 12 & Arts and Humanities & 1 & 0.31 \\
\hline 13 & Energy & 1 & 0.31 \\
\hline 14 & Materials Science & 1 & 0.31 \\
\hline 15 & Medicine & 1 & 0.31 \\
\hline & & $\mathbf{3 2 5}$ & $\mathbf{0 1 0 0}$
\end{tabular}

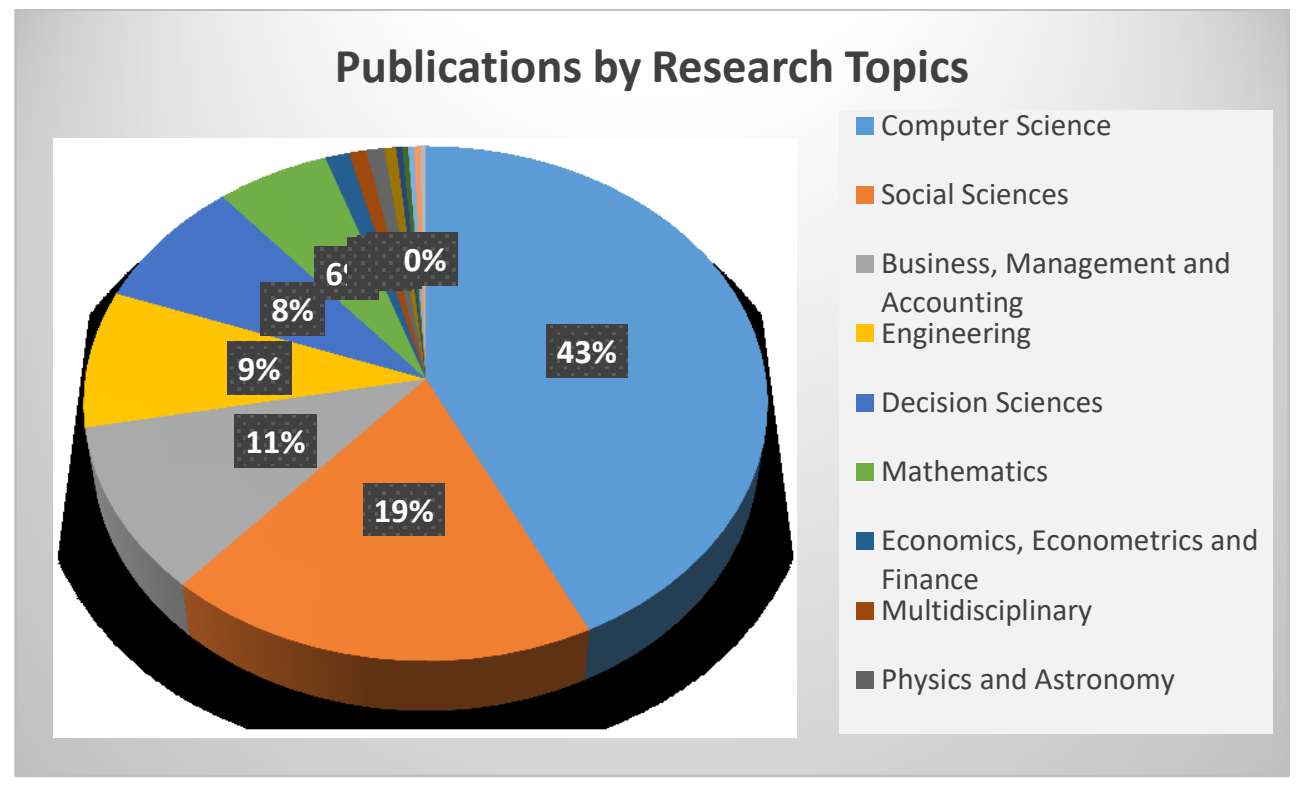




\subsection{How is the distribution of studies using the e-government and m- government according to the country of interests?}

The country of origin for publications about "e-government and $\mathrm{m}$ government" resulted in 226 countries. This means there are several publications with more than one country of origin. The highest contributing country of origin that linked to the affiliated institutions of the source of the publication in the United Kingdom with contributing 20 publications, which means the UK contributed to $8.85 \%$ of these studies, followed by the United state of 18 publication, an $8 \%$, South Africa of $5.5 \%$, India 5\%, each of (Australia, China, Germany, and Malasia) contributed by 4\%, Jordan $3.53 \%$, Greece and Iran 3.1\%, each of (Finland, Indonesia, Saudi Arabia, South Korea, Turkey) with $2.21 \%$, each of (Bahrain, Italy, and United Arab Emirates) $1.76 \%$, Eygipt, (Hungary, Indonesia, Netherland, Nigeria, and Sweden) of $1.5 \%$, and the rest of countries contributed by 1 or 2 publications which contributing by less than $1 \%$ to the outcome of the search. However, seven publications came without country of origin or undefined.

(Table 5) The distribution of the disciplines where articles about "e-government and m-government" are used

Source: Authors own conception

\begin{tabular}{llccllcc}
\hline$\#$ & $\begin{array}{c}\text { Publication } \\
\text { Country of } \\
\text { Origin }\end{array}$ & $\begin{array}{c}\text { Number } \\
\text { of } \\
\text { Articles }\end{array}$ & $\mathbf{\%}$ & & $\begin{array}{c}\text { Publication } \\
\text { Country of } \\
\text { Origin }\end{array}$ & $\begin{array}{c}\text { Number } \\
\text { of } \\
\text { Articles }\end{array}$ & $\%$ \\
\hline 1 & $\begin{array}{l}\text { United } \\
\text { Kingdom }\end{array}$ & 20 & 8.85 & 30 & Israel & 2 & 0.9 \\
\hline 2 & United States & 18 & 8 & 31 & Japan & 2 & 0.9 \\
\hline 3 & South Africa & 12 & 5.5 & 32 & Malawi & 2 & 0.9 \\
\hline 4 & India & 11 & 5 & 33 & Portugal & 2 & 0.9 \\
\hline 5 & Australia & 9 & 4 & 34 & Qatar & 2 & 0.9 \\
\hline 6 & China & 9 & 4 & 35 & Singapore & 2 & 0.9 \\
\hline 7 & Germany & 9 & 4 & 36 & Switzerland & 2 & 0.9 \\
\hline 8 & Malaysia & 9 & 4 & 37 & Taiwan & 2 & 0.9 \\
\hline 9 & Jordan & 8 & 3.53 & 38 & Tanzania & 2 & 0.9 \\
\hline 10 & Greece & 7 & 3.1 & 39 & Austria & 1 & 0.5 \\
\hline 11 & Iran & 7 & 3.1 & 40 & Azerbaijan & 1 & 0.5 \\
\hline 12 & Finland & 5 & 2.21 & 41 & Belgium & 1 & 0.5 \\
\hline 13 & Indonesia & 5 & 2.21 & 42 & Bolivia & 1 & 0.5 \\
\hline 14 & Saudi Arabia & 5 & 2.21 & 43 & Colombia & 1 & 0.5 \\
\hline 15 & South Korea & 5 & 2.21 & 44 & Denmark & 1 & 0.5
\end{tabular}


A Content Analysis on Publications Written on (E-Government and ... Huseyin BİCEN \& Shobo Najim SHALİ

\begin{tabular}{|c|c|c|c|c|c|c|c|}
\hline 16 & Turkey & 5 & 2.21 & 45 & Estonia & 1 & 0.5 \\
\hline 17 & Bahrain & 4 & 1.76 & 46 & France & 1 & 0.5 \\
\hline 18 & Italy & 4 & 1.76 & 47 & Iraq & 1 & 0.5 \\
\hline 19 & $\begin{array}{l}\text { United Arab } \\
\text { Emirates }\end{array}$ & 4 & 1.76 & 48 & Kenya & 1 & 0.5 \\
\hline 20 & Egypt & 3 & 1.5 & 49 & Mauritius & 1 & 0.5 \\
\hline 21 & Hungary & 3 & 1.5 & 50 & Mexico & 1 & 0.5 \\
\hline 22 & Macedonia & 3 & 1.5 & 51 & Oman & 1 & 0.5 \\
\hline 23 & Netherlands & 3 & 1.5 & 52 & $\begin{array}{l}\text { Papua New } \\
\text { Guinea }\end{array}$ & 1 & 0.5 \\
\hline 24 & Nigeria & 3 & 1.5 & 53 & Peru & 1 & 0.5 \\
\hline 25 & Sweden & 3 & 1.5 & 54 & Samoa & 1 & 0.5 \\
\hline 26 & Bangladesh & 2 & 0.9 & 55 & Spain & 1 & 0.5 \\
\hline 27 & Brazil & 2 & 0.9 & 56 & Thailand & 1 & 0.5 \\
\hline 28 & Canada & 2 & 0.9 & 57 & $\begin{array}{l}\text { Trinidad and } \\
\text { Tobago }\end{array}$ & 1 & 0.5 \\
\hline 29 & Czech Republic & 2 & 0.9 & 58 & Undefined & 7 & 0.5 \\
\hline
\end{tabular}




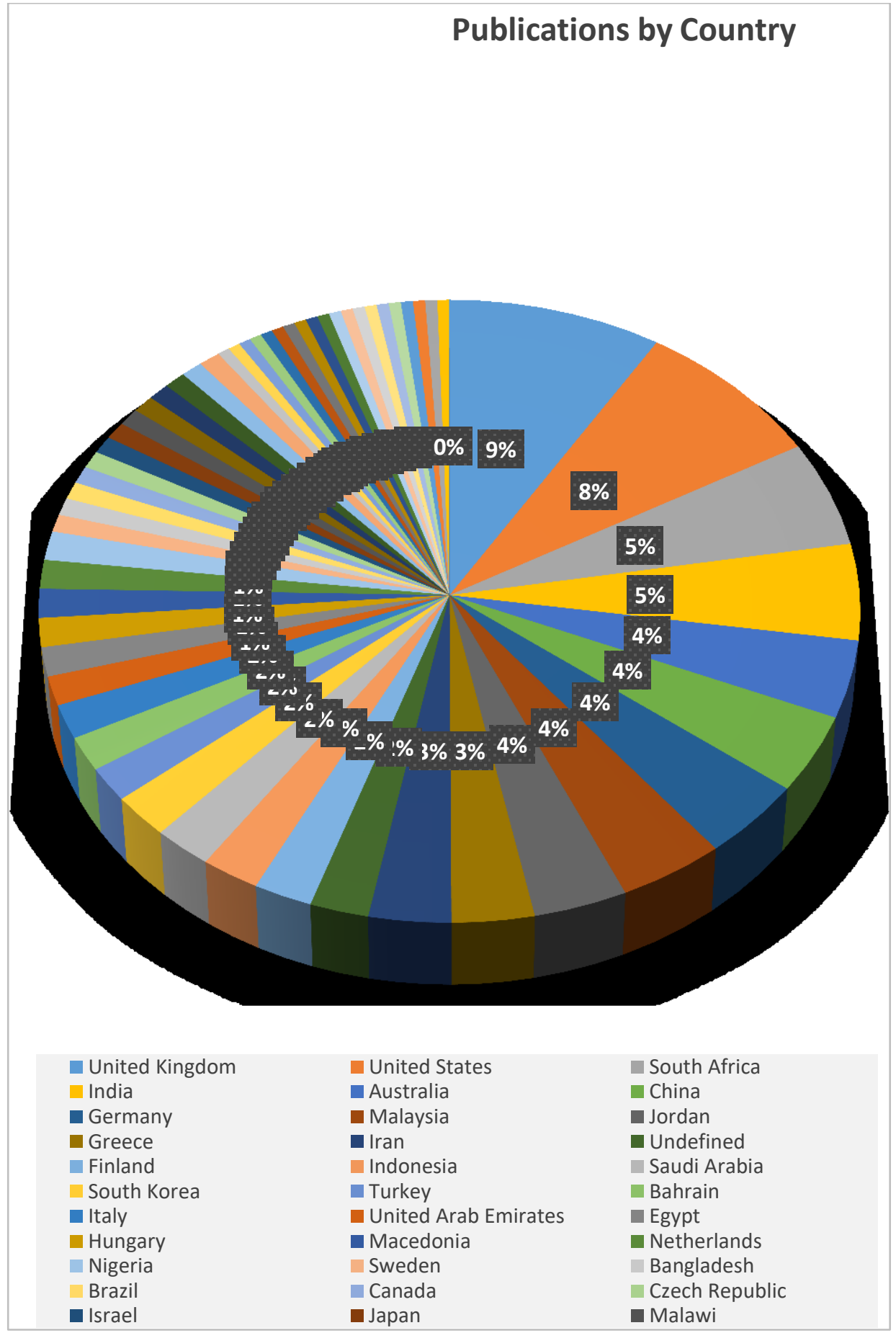




\section{Results and Discussion}

Integrating mobile government solutions into electronic government applications and processes is rapidly increasing because it creates more efficiency for people. Smartphones are one of the best tools to connect and perform daily transactions "at any time and anywhere approach" (Parcell, 2015). This approach came very useful when Covid-19 invaded the entire world in the beginning of 2020, and the world's population still suffering from this pandemic until today.

This study focused on understanding the amount of attention based on the M-government within the context of the E-government. This goal was determined by analyzing the number of publications that were published from one particular website database, the (Scopus), within the last 11 years from 2000 to 2020.

When the distribution map of studies on the frequent use of "egovernment and m-government" including term equivalents, analyzed by types of assignments (Table 1), the highest number of publication type appeared to be the Conference Papers with $48.92 \%$, followed by Articles $32.06 \%$, Book Chapters 14.13\%, Conference Reviews 3.27\%, and each of (Book, Editorial and Review Papers) with less than 1\% which was $0.54 \%$, this indicates the amount of attention given by professionals in exposing the subjects and discussing them at the professional levels. On the other hand, Books were the least of concerns from academics and professional institutions.

The importance of the period is based upon the era of web 2.0 tools developments, including internet developments and smartphones. When the distribution map of studies on the frequent use of "e-government and mgovernment" including term equivalencies like "Electronic Government, Mobile Government, E-Gov., and M-Gov", analyzed by years (Table 2), there was a total of 184 publications, the highest number of studies observed between $2000-2021$ was $8.7 \%$ in 2020 . These studies were followed by those done in 2010 (with 8.2\%), 2013, and 2014 (with 7.6\%). However, 3.3\% of studies published in the recent year 2021 so far, and this rate might change by the end of this year as other scholars might add to this table of accomplishment. In addition, the research found no publications posted before 2003, which means the attention to this subject did not initiate or not posted on Scopus before 2003. The data analysis showed graduate increase toward 2010 and graduate decrease toward 2020. Then it reached a peak in 2020, which explained by the pandemic situation. 
When it comes to the number of authors in the areas of "egovernment and m-government" studies who contributed to 184 publications, six levels of contributions and 239 authors found (Table 3). That means multiple people contributed to the same publications. In other words, some publications were published under more than one author. On the other hand, some authors contributed to more than one publication. The single highest contributing author contributed by (5) publications, followed by (3) authors contributed to (4) publications, and (12) authors contributed to (3) publications, followed by (37) authors with (2) publications and (106) singled authored publication. However, in this research, six articles were found with undefined authors. If we calculate each author's effort to the total work of 184 publications, we find each author contributed by $0.625 \%$.

Regarding the discipline interests in publications of "e-government and m-government," the disciplines included in related publications (Table 4) and studies have 15 categories of disciplines areas of total 325 covered in the 184 publications, this means some publications covered more than one area of discipline. Computer Science is the most common place to look for research in these fields, the highest with $42.76 \%$, followed by Social Sciences of $18.76 \%$, Business, Management and Accounting of $10.46 \%$, Engineering 8.61\%, Decision Sciences 8.31\%, Mathematics 5.84\%, Economics, Econometrics and Finance 1.24\%, both Multidisciplinary and Physics and Astronomy $0.93 \%$, Environmental Science $0.61 \%$, and each of (Agricultural and Biological Sciences, Arts and Humanities, Energy, Materials Science, plus Medicine) participated by less than $1 \%$, which was equivalent to $0.31 \%$ of the total discipline.

The country of origin is linked to affiliated institutions that adopting studies. When it came to the country of origin for these 184 publications about "e-government and m-government," it resulted in 226 countries. This means there are many publications with more than one country of origin, which means multiple institutions joined efforts in the contribution of these researches as shown in (Table 5). This study shows the highest contributing country as an origin of the affiliated institution to the publication in the United Kingdom, contributing to 20 publications in that period. In other words, UK contributed to $8.85 \%$ of these studies with 20 publications, followed by the United state with 18 publication of 8\%, then South Africa of $5.5 \%$, India 5\%, each of (Australia, China, Germany, and Malasia) contributed by $4 \%$, Jordan $3.53 \%$, Greece and Iran 3.1\%, and each of (Finland, Indonesia, Saudi Arabia, South Korea, Turkey) with 2.21\%, each of (Bahrain, Italy, and United Arab Emirates) 1.76\%, (Egypt, Hungary, Indonesia, Netherland, Nigeria, and Sweden) $1.5 \%$, and the rest of countries 
contributed by 1 or 2 publications which will be less than $1 \%$ to the outcome of the search. However, the study shows seven publications came without country of origin or undefined country.

\section{Limitations}

This study is restricted to a single website. More testing, extending to numerous target websites, is needed to reproduce and verify the approach's functionality. In order to compare and enrich the findings, future studies should combine the quantitative and qualitative approaches in the framework of content analysis ( Vitouladiti, 2013).

\section{References}

Berelson, B. (1952). Content analysis in communication research. Free Press.

Bicen, H., \& Ozdamli, F., \& Uzunboylu, H. (2012). Online and blended learning approach on instructional multimedia development courses in teacher education. Interactive Learning Environments, 22(4), 529-548. http://dx.doi.org/10.1080/10494820.2012.682586

Jawabreh, R., \& Bicen, H. (2020). Content analysis of articles that related to the use of google classroom and gamification in education from 2016 to 2020.

Near East University Online Journal of Education, 3(2), 53-65. https://doi.org/10.32955/neuje.v3i2.247

Krippendorff, K. (2012). Content analysis: An introduction to its methodology (Second Edition). Sage Publications.

Kushchu, I., \& Kuscu, M. H. (2016). From E-government to M-government: Facing the Inevitable. Mobilegov UK.

OECD. (2017, February 12-14) Embracing Innovation in Government: Global Trends. World Government Summit, Dubai, United Arab Emirates, 12-14 February 2017. OECD publication. Retrieved August 10, 2021, fromhttps://www.oecd.org/innovation/innovativegovernment/embracing-innovation-in-government-global-trends.htm

Parcell, J. (2015,), How Government will Accelerate Anytime, Anywhere Services and Information in 2015. Digital.Gov. GSA | Washington D.C. Retrieved August 10, 2021, from https:// digital.gov/2015/01/29/how-governmentwill-accelerate-anytime-anywhere-services-and-information-in-2015/

Silver, L. (2019,). Smartphone Ownership Is Growing Rapidly Around the World, but Not Always Equally. Pew Research Center. Retrieved August 10, 2021, from https://www.pewresearch.org/global/smartphone-ownership-isgrowing-rapidly-around-the-world-but-not-always-equally/

Stemler, S. (2000). An overview of content analysis. Practical Assessment, Research, and Evaluation, 7, 17. https://doi.org/10.7275/z6fm-2e34 
Vitouladiti, O. (2014). Content Analysis as a Resear ch Tool for Marketing Management and Development Str ategies in Tourism. Procedia - Economics and Finance, 9, 278-287. https://doi.org/10.1016/S2212-5671(14)00029-X 